\title{
The possible involvement of tubulin in transduction of the prolactin signal
}

\author{
LM Houdebine
}

INRA, Unité de Différenciation Cellulaire, 78350 Jouy-en-Josas, France

(15th meeting of the INRA development group, Paris, 24-26 May 1989)

\begin{abstract}
Summary - Polactin has many different biological functions. It stimulates $\mathrm{Nb}_{2}$ cell multiplication through the kinase $C$ transduction mechanism, casein secretion through the phospholipase $A_{2}$ arachidonic acid-leukotriens cascade and milk protein gene expression through an unknown mechanism. Colchicine and other tubulin binding drugs inhibit casein gene expression and DNA synthesis stimulated by prolactin whereas chemical compounds which alter microtubule without binding tubulin exert no inhibitory effect. Myo-inositol which suppresses some of the colchicine actions in several biological systems does not restore prolactin action after an inhibition by the drug. These data suggest that a tubulin molecule in the vicinity of the prolactin receptor, rather than actual microtubules, is involved in the transduction of the prolactin message from its receptor to milk protein genes.
\end{abstract}

prolactin / casein synthesis / tubulin / microtubule / colchicine / transduction

Résumé - Le rôle de la tubuline dans la transduction du message prolactinlque. La prolactine a beaucoup de fonctions biologiques différentes. Elle stimule la multiplication des cellules $\mathrm{Nb}_{2}$ en empruntant le système de transduction par l'intermédiaire de la kinase $C$, elle stimule la sécrétion des protéines du lait par la voie phospholipase $A_{2}$-acide arachidonique-leucotriènes et elle stimule l'expression des gènes des protéines du lait et la synthèse de l'ADN dans la cellule mammaire par un mécanisme inconnu. La colchicine et un certain nombre d'autres drogues liant la tubuline s'opposent aux effets de la prolactine tandis que d'autres composés chimiques destabilisant les microtubules sans se lier à la tubuline ne s'y opposent pas. Le myo-inositol qui, dans plusieurs systèmes biologiques, supprime certains effets inhibiteurs de la colchicine, n'est pas capable de restaurer l'action stimulatrice de la prolactine en présence de la drogue. Ces faits suggèrent qu'une tubuline membranaire voisine du récepteur de la prolactine, plutôt que les structures microtubulaires proprement dites, est impliquée dans la transduction du message prolactinique.

prolactine / synthèse de caséine / tubuline / microtubule / colchicine / transduction 


\section{INTRODUCTION}

Prolactin has many known functions (Nicoll, 1980). Its mechanism of action is studied in only a limited number of tissues for a limited number of actions including:

- cell multiplication (Russell et al, 1987) (with mainly $\mathrm{Nb}_{2}$ cells as experimental model);

- stimulation of gene expression (Devinoy et al, 1988) (with essentially milk protein gene as target genes);

- stimulation of protein secretion (OllivierBousquet, 1984) (with mammary cell and milk secretion as an experimental model).

The prolactin receptor has been identified and recent studies have led to the cloning of its cDNA (Boutin et al, 1988). Transduction of the prolactin message beyond the receptor is mediated through an unknown mechanism which may or may not be a single mechanism. In the case of liver cells, nuclear kinase $C$ is directly stimulated by prolactin added to isolated nuclei (Buckley et al, 1988). $\mathrm{Nb}_{2}$ cell multiplication is stimulated by prolactin with a coincident increase of kinase C (Russell et al, 1987). The mechanism which transfers the prolactin message from its receptor to kinase $C$ is unknown. Stimulation of milk secretion by prolactin is inhibited by various inhibitors of the phospholipids-arachidonic acid-leukotriens pathway and phospholipase $\mathrm{A}_{2}$ mimic this prolactin action (Ollivier-Bousquet, 1984). The molecular mechanism between prolactin receptor and phospholipase $A_{2}$ remains unknown. In the case of casein gene expression, it is clear that a transduction mechanism is involved at the receptor level since anti-prolactin receptor antibodies mimic prolactin for the induction of casein synthesis (Djiane et al, 1981). Interestingly, prolactin stimulates DNA synthesis in cultured mammary explants (Houdebine, 1980), an effect also mimicked by anti-prolactin receptor antibodies (Djiane et al, 1981).
Very little is known about the molecular events which transfer the prolactin message from its receptor to milk protein genes (Houdebine et al, 1985; Devinoy et al, 1988, 1989). Studies carried out for several years have shown that colchicine and other drugs totally inhibit the prolactin stimulation of casein and DNA synthesis. The present paper summarizes these data and reveals some new experimental results.

\section{MATERIALS AND METHODS}

All the methods have been described in previous papers. Culture of mammary explants was carried out in serum-free medium in the presence of hormones. $\beta$-casein synthesis was estjmated with a specific radioimmunoassay and $\beta$ casein mRNA concentration was measured using a specific cDNA probe (Zwierzchowski et al, 1987). Isolated epithelial mammary cells were cultured on floating collagen gel as previously described. $\beta$-casein was then measured in the cultured medium (Servely et al, 1987).

\section{RESULTS}

\section{Effect of colchicine and other tubulin binding drugs on casein gene expression}

Colchicine added at a millimolar concentration totally inhibits the induction of casein synthesis by prolactin (Houdebine and Djiane, 1980). This effect does not profoundly affect the prolactin receptor which remains down-regulated by the hormone (Djiane et al, 1980). This inhibition is also observed when prolactin is present in the culture medium without its major amplifiers, insulin and cortisol (Servely et al, 1987). Prolactin stimulated both casein synthesis and total protein synthesis. Colchicine inhibits both effects (Houdebine and Djiane, 1980). 
Several other drugs known to disrupt microtubules after binding tubulin (vinblastin, podophyllotoxin, nocodazole, colcemide, tubulozole $\mathrm{C}$ ) also strongly inhibit the induction of casein synthesis (Houdebine, 1980; Servely et al, 1987) whereas colchicine analogues (lumicolchicine, trimethylcolchicinic acid and colchicine) which do not alter microtubule structure do not prevent prolactin from acting (fig 1). The active drugs do not only affect casein secretion. Rather, they have a profound effect on prolactin action since $\beta$-casein mRNA accumulation is simultaneously blocked (Servely et al, 1987).

\section{Effect of drugs which disrupt microtubule without binding tubulin on casein gene expression}

Several chemical compounds are known to alter microtubules although they do not bind tubulin. Griseofulvin and estramustine are potent microtubule disrupting drugs acting by binding microtubule associated proteins. When added to the culture medium of mammary explants, these drugs profoundly alter microtubule integrity yet they do not prevent prolactin from inducing casein synthesis (Houdebine et al, 1982; Zwierzchowski et al, 1987).

Similarly, several local anesthetics, procaine, tetracaine and dibucaine do not alter prolactin action on casein gene expression, although they markedly modify cytoskeleton structure (Houdebine et al, 1981).

\section{Kinetics of colchicine action on casein gene expression}

Colchicine and related drugs are considered to act rapidly on microtubules, and

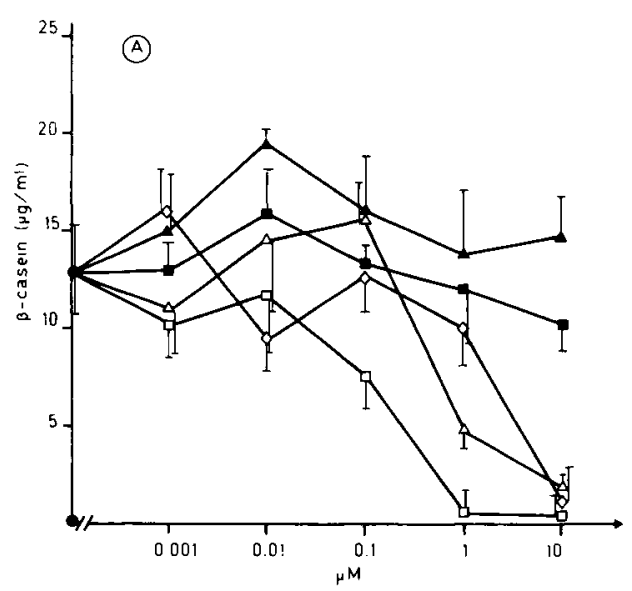

Fig 1. Effect of several tubulin binding drugs on the induction of $\beta$-casein synthesis in rabbit mammary cells. Cells were cultured for $3 \mathrm{~d}$ and then induced for $3 \mathrm{~d}$ in the presence of prolactin, insulin and cortisol with or without drugs. $\beta$ casein in the medium was measured at the end of the culture. (O) insulin + cortisol; $(\mathrm{O}-\mathrm{O})$ insulin (I) + cortisol (C) + prolactin (PRL); ( $\square-$ 口) $1+C+P R L+$ colchicine; $(\square) ~ I+C+P R L$ + lumicolchicine; $(0-0) \mathrm{I}+\mathrm{C}+\mathrm{PRL}+$ nocodazole; $(\Delta-\Delta) \mathrm{l}+\mathrm{C}+\mathrm{PRL}+$ tubulozole $\mathrm{C} ;(\mathbf{\Delta}-\mathbf{\Delta})$ $\mathrm{I}+\mathrm{C}+\mathrm{PRL}+$ tubulozole $\mathrm{T}$.

phenomena such as secretion are quickly affected. This is also the case for casein secretion which is markedly and rapidly inhibited by colchicine (Ollivier-Bousquet and Denamur, 1973). Surprisingly, the effect of colchicine, vinblastin, podophyllotoxin, nocodazole and gossipol on $\beta$-casein mRNA accumulation is not observed after a period as long as $8 \mathrm{~h}$, whereas it is unambiguously seen after $24 \mathrm{~h}$ (Devinoy et al, 1988).

Taxol is known to prevent disruption of microtubule induced by colchicine. This compound added with several tubulin binding drugs is unable to completely restore prolactin stimulation (Devinoy et al, 1988). This fact must however be interpreted with 
caution, since taxol per se attenuates prolactin effect.

\section{Effect of tubulin binding drugs on DNA synthesis}

The above-mentioned drugs which inhibit prolactin action on casein synthesis are all capable of also inhibiting the hormonal effect on DNA synthesis (Houdebine, 1980; Houdebine and Djiane, 1980). On the contrary, the drugs which do not affect casein synthesis induction are ineffective in preventing DNA synthesis stimulation by prolactin (Houdebine et al, 1981, 1982; Zwierzchowski, 1987).

Interestingly and unexpectedly, the tubulin binding drugs are capable of inhibiting not only the stimulation of DNA synthesis by prolactin, but also the stimulation by insulin and EGF (Martel and Houdebine, 1982).

Not surprisingly however, the prolactinlike effect of anti-prolactin receptor antibodies on DNA synthesis was totally suppressed by the tubulin binding drugs (Djiane et al, 1981).

\section{The possible relation between colchicine and phospholipase $C$}

In several reports, it is mentioned that colchicine strongly inhibits the phospholipase C which hydrolyses phosphatidylinositides (Schellenberg and Gillespie, 1977).

Several experiments not depicted here suggest that this type of phospholipase $C$ mimics or stimulates a somewhat prolactin action on $\beta$-casein mRNA accumulation. These experiments cannot be reproduced in all cases and it is therefore unclear if phospholipase $C$ is involved in prolactin action. More convincing is the fact that ne- omycin, a potent inhibitor of phosphatidylinositides hydrolysis (Carney et al, 1985), totally abrogates $\beta$-casein accumulation induced by prolactin (fig 2). However, neomycin is known to have other inhibitory effects and the possible involvement of phospholipase $\mathrm{C}$ in prolactin action cannot be ascertained from the only experiments described here.

In several biological systems, colchicine strongly inhibits phospholipase $\mathrm{C}$ and this inhibition is alleviated by an excess of myo-inositol but not by its analogue epiinositol (Murray et al, 1951; Lymberopolous and Hawthorne, 1980). On the other hand, myo-inositol may circumvent a lack of phosphatidylinositol (Rodriguez et al, 1987).

Myo-inositol does not mimic or alter prolactin action and it is unable to alleviate the inhibitory effect of colchicine on $\beta$-casein mRNA accumulation (fig 2). These data suggest that colchicine inhibitory effect is not mediated through an inhibition of phospholipase C.

\section{CONCLUSION}

The data reported in the present paper argue strongly in favour of the idea that the integrity of tubulin is required for the transduction of the prolactin message from its receptor to milk protein genes. The fact that several drugs which destabilize the microtubular network without binding directly to tubulin, support the view that it is tubulin per se, rather than actual microtubules, which is involved in prolactin action. Tubulin has several molecular isoforms and at least 1 of them contains a structure which anchors the molecule in membranes. Tubulin or colchicine binding molecules have been found in several tissues including the mammary gland (Feit and Barondes, 1970; Lagnado et al, 1971; Stadler and Franke, 


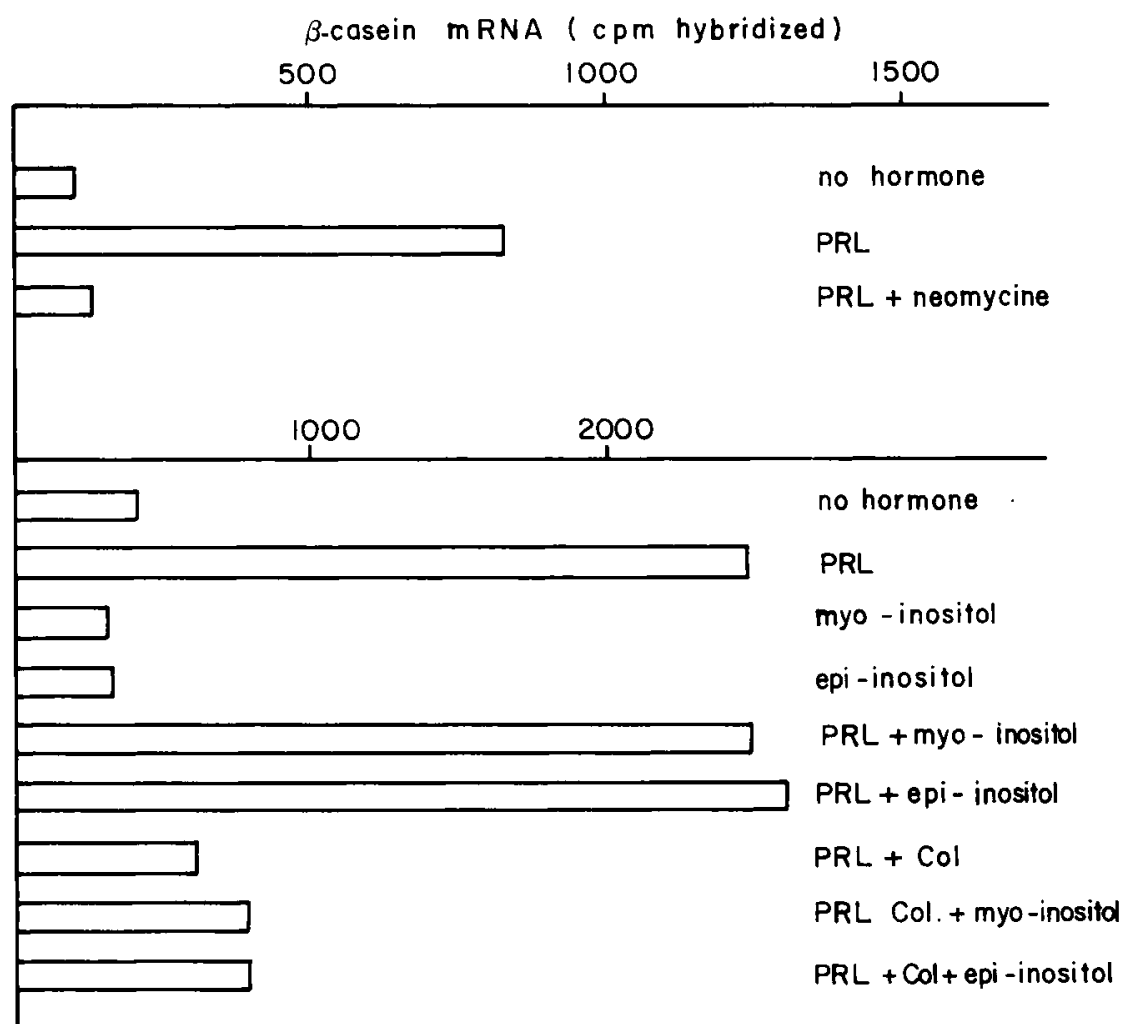

Fig 2. A Inhibition of $\beta$-casein mRNA accumulation by neomycin. The antibiotics were added with prolactin and $\beta$-casein mRNA was evaluated 8 hours after the beginning of the stimulation. $B$ Effect of myo-inositol on the inhibition of $\beta$-casein mRNA accumulation. Mammary explants were cultured for $1 \mathrm{~d}$ in the presence of prolactin $1 \mu \mathrm{g} / \mathrm{ml}$ with or without colchicine $(1 \mathrm{mmol} / \mathrm{h})$. Casein mRNA was measured at the end of the culture.

1972, 1974; Bhattacharyya and Wolff, 1975, 1976; Houdebine et al, 1982). It is tempting to speculate that a tubulin molecule not recruited in a microtubular structure but anchored in the membranes in the vicinity of the prolactin receptor is involved in the transduction of the hormonal signal. Interestingly, the possible involvement of tubulin in the transmission of other signals through membranes has been reported (Wang et al, 1975; Chen et al, 1976; Gunther et al, 1976; Marks et al, 1978; Zor et al, 1978; Marks et al, 1980; Simonin et al, 1981; Carter et al, 1989; Ravindra et al, 1989). The fact that phospholipids were found to be associated with microtubular proteins, including tubulin (Hargreaves and McLean, 1988) further supports this view.

It is not clear how tubulin might interfere with the prolactin mechanism of action. It is reasonable to rule out the idea that cell multiplication is involved in this process. Indeed, at mid-pregnancy, rabbit mammary cells can differentiate without any previous cell multiplication and experimentally in the 
presence of hydroxy-urea which blocks DNA synthesis (Houdebine and Djiane, 1980). The fact that stimulation of milk protein gene expression and DNA synthesis by prolactin are simultaneously inhibited strongly argues in favour of the idea that the prolactin mechanism of action is interrupted in one of its early steps, most likely at the membrane level after the binding of the hormone to its receptor. The observation that the insulin and EGF signals for DNA are also blocked by colchicine suggests that tubulin is functionally linked in some way to several membrane receptors. Experiments not shown here and based on the use of antitubulin antibodies to block tubulin action at the ceilular level did not give unambiguous information. Indeed, these antibodies were unable to alter prolactin action on casein gene expression. The antibodies may have been unable to reach the membrane tubulin, and these experiments must be considered as inconclusive rather than arguing against the direct participation of membrane tubulin in prolactin action. Experiments which are in progress using primary mammary cells in culture should determine if colchicine prevents prolactin from stimulating casein gene transcription. If this happens to be the case, these experiments will bring a strong argument in favour of the hypothesis that it is the whole prolactin message which is blocked by the anti-tubulin drugs at the membrane level.

Colchicine and related drugs have been shown to markedly decrease the uptake of ovine prolactin into the liver Golgi light and intermediate fractions (Posner et al, 1982). This observation and the data reported here support the view that the endocytosis of the prolactin-receptor complex is required for the hormone to deliver its message to milk protein genes.

The fact that colchicine and related drugs act at the membrane level does not eliminate the idea that microtubule or more generally cytoskeleton is an essential structure in mammary cell differentiation. Indeed, cytochalasin D (Blum and Wicha, 1988) although not cytochalasin B (Houdebine and Djiane, 1980) which disrupts microfilaments, prevents milk protein mRNA from accumulating without altering transcription level of these genes (Wicha et al, unpublished data). It is therefore the halflife of milk protein mRNA which is then affected rather than the transmission of the hormonal message to genes. The fact that milk protein mRNA were found to be associated with cytoskeleton further supports this view (Aggeler et al, unpublished data). More generally, it is the whole cell structure which seems to be involved in the transmission of the hormonal message and in the differentiation process of the mammary cell (Aggeler et al, 1988). The observation that the extracellular matrix, which is known to play an essential role in mammary cell polarization and differentiation, enhances milk protein mRNA concentration without any simultaneous increase of milk protein gene transcription (Eisenstein and Rosen, 1988) brings additional support to this idea.

It is not known if colchicine and related drugs are also able to block the prolactin signal triggering milk secretion, and this stimulation of $\mathrm{Nb}_{2}$ cell multiplication. It is not easy to evaluate the effect of colchicine on the stimulation of secretion since the drug is per se a strong biocker of the secretion process. To the best of our knowledge, the effect of colchicine on the stimulation of DNA synthesis by prolactin in $\mathrm{Nb}_{2}$ cells has not been examined.

\section{ACKNOWLEDGMENTS}

This work was carried out with the excellent technical assistance of $\mathrm{C}$ Puissant and $\mathrm{H}$ Gra- 
bowski. It was supported by the financial help of the Biotechnology Action Program (BAP) of the European Community.

\section{REFERENCES}

Ageller J, Park CS, Bissell MJ (1988) Regulation of milk protein and basement membrane gene expression. The influence of the extracellular matrix. J Dairy Sci 71, 2830-2842

Battacharyya B, Wolff F (1975) Membranebound tubulin in brain and thyroid tissue. $J$ Biol Chem 250, 7639-7646

Battacharyya B, Wolff F (1976) Polymerisation of membrane tubulin. Nature 264, 576-577

Blum JL, Wicha MS (1988) Role of the cytoskeleton in laminin induced mammary cell expression. J Cell Physiol 135, 13-22

Boutin JM, Jolicoeur C, Okamura H, Gagnon J, Edery M, Shirota M, Banville D, Dusanter I, Djiane J, Kelly PA (1988) Cloning and expression of the rat prolactin receptor, a member of the growth hormone/prolactin receptor gene family. Cell 5, 369-377

Buckley AR, Crowe PD, Russell DH (1988) Rapid activation of protein kinase $C$ in isolated rat liver nuclei by prolactin a known hepatic mitogen. Proc Natl Acad Sci USA 86, 8649-8653

Carney DH, Scott DL, Gordon EA, Labelle EF (1985) Phosphoinositides in mitogenesis neomycin inhibits thrombase stimulated phosphoinositide turnover and initiation of cell proliferation. Cell 42, 479-488

Carter KC, Cooper R, Papaconstantinou J, Ritchie DG (1989) Microtubule depolymerization inhibits the regulation of $\alpha_{1}$-acid glycoprotein mRNA by hepatocyte stimulating factor. J Biol Chem 264, 515-519

Chen K, Heller J, Cannelakis ES (1976) Studies in the regulation of ornithing decarboxylase activity by the microtubules: the effect of colchicine and vinblastin. Biochem Biophys Res Commun 68, 401-409

Devinoy $E$, Hubert $C$, Jolivet $G$, Thépot D, Clergue N, Desaleux M, Dion M, Servely JL, Houdebine LM (1988) Recent data on the structure of rabbit milk protein genes and on the mechanism of the hormonal control of their expression. Reprod Nutr Dev 28, 11451164
Devinoy E, Jolivet G, Thépot D, Houdebine LM (1989) Prolactin control of milk protein gene expression in the rabbit mammary gland. In: 8th Workshop on Development and Function of Reproductive Organs. Serono Symposia Rev No 21, vol III, 21-36

Djiane J, Kelly PA, Houdebine LM (1980) Effects of lysosomotropic agents, cytochalasin $B$ and colchicine on the down-regulation of prolactin receptors in mammary gland explants. Mol Cell Endocrinol 18, 87-98

Djiane J, Houdebine LM, Kelly PA (1981) Prolactin-like activity of anti-prolactin receptor antibodies on casein and DNA synthesis in the mammary gland. Proc Natl Acad Sci USA 78, 7445-7448

Eisenstein RS, Rosen JM (1988) Both cell substratum regulation and hormonal regulation of milk protein gene expression are exerted primarily at the post-transcriptional level. Mol Cell Biol 8, 3183-3190

Feit H, Barondes SH (1970) Colchicine-binding activity in particulate fractions of mouse brain. J Neurochem 17, 1355-1364

Gunther GR, Wang JL, Edelman GM (1976) Kinetics of colchicine inhibition of mitogenesis in individual lymphocytes. Exp Cell Res 98, 15-22

Hargreaves AJ, McLean WG (1988) The characterization of phospholipids associated with microtubules, purified tubulin and microtubule associated proteins in vitro. Int J Biochem 20 , 1133-1138

Hawthorne JN (1988) Phosphoinositides and metabolic control: how many messengers? Biochem Soc Trans 16, 657-660

Houdebine LM (1980) Effect of various lysosomotropic agents and microtubule disrupting drugs on the lactogenic and the mammogenic action of prolactin. Eur J Cell Biol 22, 755760

Houdebine LM, Djiane J (1980) Effects of lysosomotropic agents and microfilament - and microtubule- disrupting drugs on the activation of casein-gene expression by prolactin in the mammary gland. Mol Cell Endocrinol 17, 1-15

Houdebine LM, Djiane J, Ollivier-Bousquet $M$ (1981) Effect of local anesthetics on the transmission of prolactin message to casein genes and on down-regulation of prolactin receptor. Biol Cell 41, 231-234 
Houdebine LM, Ollivier-Bousquet $M$, Djiane J (1982) Rôle des protéines membranaires liant la colchicine dans la transmission du message prolactinique aux gènes des caséines dans la glande mammaire de lapine. Biochimie 64, 21-28

Houdebine LM, Djiane J, Dusanter-Fourt I, Martel P, Kelly PA, Devinoy E, Servely JL (1985) Hormonal action controlling mammary activity. J Dairy Sci 68, 489-500

Lagnado JR, Lyons C, Wickremasinghe G (1971) The subcellular distribution of colchicine-binding protein (microtubule protein) in rat brain. FEBS Lett 15, 254-258

Lymberopoulos G, Hawthorne JN (1980) Inhibition by myoinositol of the anti-mitotic effect of colchicine on rat fibroblasts and rat intestinal micosa. Exp Cell Res 129, 409-414

Marks A, Mahony JB, Brown IR (1978) Colchicine inhibits the accumulation of messenger RNA for a brain specific protein in rat glial cells. Biochem Biophys Res Commun 82, 1306-1313

Marks A, Thibault J, Whalen R, Mahony JB, Law J, Gros F (1980) Selective action of colchicine on protein synthesis and release in a clonal live of rat glial cells. Biochimie 62, 705-712

Martel P, Houdebine LM (1982) Effects various drugs affecting cytoskeleton and plasma membranes on the induction of DNA synthesis by insulin, epidermal growth factor and prolactin in mammary explants. Biol Cell 44, 111-116

Murray MR, de Lam HH, Chargaff E (1951) Specific inhibition by meso-inositol of the colchicine effect on rat fibroblasts. Exp Cell Res 2, 165-177

Nicoll CS (1980) Prolactin Fed Proc 39, 25612562

Ollivier-Bousquet M (1984) Effet de la prolactine sur la sécrétion des caséines du lait : métabolisme de l'acide arachidonique. Biol Cell 51, 319-323

Ollivier-Bousquet M, Denamur R (1973) Inhibition par la colchicine de la sécrétion des protéines du lait. CR Acad Sci Paris 276, 21832185

Posner BI, Verma AK, Patel BA, Bergeron JJM (1982) Effect of colchicine on the uptake of prolactin and insulin into Golgi fractions of rat liver. J Cell Biol 93, 560-567
Ravindra R, Dennison RL, Narayanan TK, Aronstam RS (1989) Influence of colchicine on the basal and receptor stimulated GTPase activity of $G$ proteins in rat stratum. FASEB $J$ 3, A1293

Rodriguez R, Atsuchi I, Gershengorn MC (1987) Phosphatidyl depletion in $\mathrm{Gh}_{3}$ rat pituitary cells inhibit sustained responses to thyrotropin-releasing hormone. Reversal with myoinositol. Mol Endocrinol 1, 802-807

Russell DH, Buckley AR, Montgomery DW, Larson NA, Gout PW, Beer CT, Putnam CW, Zukowski CF, Kibler R (1987) Prolactindependent mitogenesis in $\mathrm{Nb}_{2}$ node lymphoma cells: effects of immunosuppressive cyclopeptides. J Immunol 138, 276-284

Schellengerg RR, Gillespie E (1977) Colchicine inhibits phosphatidyl turnover induced in lymphocytes by concanavalin A. Nature 265, 741-742

Servely JL, Geuens GMA, Martel P, Houdebine LM, De Brabander M (1987) Effect of tubulozole, a new synthetic microtubule inhibitor, on the induction of casein gene expression by prolactin. Biol Cell 59, 121-128

Simonin G, Zachowski A, Huitorel P, Pantaloni $D$, Paraf $A$ (1981) Stimulation by tubulin of an adenylate cyclase from Murine Plasmacytoma. Eur J Biochem 118, 515-519

Stadler J, Franke WW (1972) Colchicine-binding proteins in chromatin and membranes. $\mathrm{Na}$ ture 237, 237-238

Stadler J, Franke WW (1974) Characterization of the colchicine binding of membrane fractions from rat and mouse liver. $J$ Cell Biol 60 , 297-303

Wang JL, Gunther GR, Edelman GM (1975) Inhibition by colchicine of the mitogenic stimulation of lymphocytes prior to the $S$ phase. Exp Cell Res 66, 128-144

Zor V, Stulovici B, Linder HR (1978) Implication of microtubules and microfilaments in the response of the ovarian adenylate cyclasecyclic AMP system to gonadotropin and prostaglandin $\mathrm{E}_{2}$. Biochem Biophys Res Commun 80, 983-992

Zwierzchowski L, Fléchon J, Ollivier-Bousquet M, Houdebine LM (1987) Effects of estramustine, a new anti-microtubule drug, on the induction of casein gene expression by prolactin. Biol Cell 61, 51-57 